\title{
CÉLORSZÁG-PREFERENCIÁK AZ ELVÁNDORLÁST TERVEZŐ MAGYAR ORVOSOK KÖRÉBEN
}

\author{
Golovics József
}

\section{ÖSSZEFOGLALÓ}

Jelen tanulmány az elvándorlást tervező magyar állampolgárságú orvosok célország-preferenciáit vizsgálja 2010 és 2019 közötti időszakra vonatkozóan az Állami Egészségügyi Ellátó Központ által kiadott, külföldi munkavállaláshoz szükséges hatósági bizonyítványok adatai alapján. A statisztikák áttekintése mellett kereszttáblás elemzésekben, függetlenségvizsgálat és asszociációs kapcsolat mérése révén azt kívánjuk feltárni, hogy beazonosítható-e valamilyen mintázat a külföldi munkavállalást tervező orvosok célország-választása, valamint neme, kora, lakhelye és szakvizsga-típusa között. Mindezek során az egyes célországok kereslet oldali vonzó hatásait is figyelembe vesszük. A statisztikai vizsgálatok eredményei rendre gyenge kapcsolatokra utalnak, azonban több jellemző motívum kiemelhető a fő célországok tekintetében. Németország iránt erőteljes érdeklődés mutatkozik a fiatal orvosok körében, míg az Egyesült Királyságot inkább a tapasztaltabbak célozzák meg. Akik az utóbbin szándékoznak munkát vállalni, azok nagy valószínűséggel meg is valósítják e terveiket. Ausztria potenciális ingázási célpont a nyugati határhoz közeli megyék orvosai számára, míg a svédországi desztinációt a patológusok választják leginkább.

Tárgyszavak: migráció, elvándorlás, orvos-elvándorlás

Golovics József PhD, egyetemi adjunktus, Budapesti Corvinus Egyetem,

Összehasonlító és Intézményi Gazdaságtan Tanszék

E-mail: jozsef.golovics@uni-corvinus.hu 


\section{BEVEZETÉS}

A modern társadalmak fenntarthatóságának egyik legfontosabb pillérét az egészségügyi rendszer jelenti, amelynek müködőképességét többek között a benne dolgozó személyek biztosítják. Mindezt az elmúlt két évben zajló globális koronavírus-járvány is megerősítette. A munkaerőhiány problémája azonban - párhuzamosan az elöregedő társadalmakra jellemző egészségügyi szolgáltatások iránti kereslet növekedésével - évtizedes távlatban erőteljesen jelen van a szektorban, nem csak Magyarországon, hanem Európában, illetve a világ többi részén is (Glinos, 2014; Jonsson et al., 2020; Lorkowski és Jugowicz, 2020). A hazai helyzetet jól szemlélteti, hogy 2021 decemberében az Országos Kórházi Főigazgatóság (2022) országosan 578 tartósan betöltetlen háziorvosi körzetről adott jelentést, amelyek jelentős része már több, mint 12 hónapja, de nem elenyésző részük akár 10-15 éve is ebben a státuszban vannak. A teljes szektorban, a humánegészségügy és szociális ellátás területén a Központi Statisztikai Hivatal [KSH] (2022) adatai szerint 2021 negyedik negyedévében az álláshelyek 3,6\%-a (mintegy 8,3 ezer álláshely) volt üres, amely érdemben meghaladta a nemzetgazdasági átlagot (2,5\%).

A magyarországi orvoshiány a pályaelhagyás mellett főként az elvándorlással magyarázható (Varga, 2016). Ahogy arra Balázs (2012) is rámutatott, a külföldre távozó orvosok száma már 2008-ban meghaladta a rendszerbe újonnan belépő diplomásokét, valamint ez az olló a következő években csak tovább nyílt. 2012-re Hárs és Simon (2016) már 3246 före becsülte a külföldön tartózkodó orvosok állományának nagyságát. Jóllehet az itthon maradók migrációs potenciálja a 2010-es évek második felében csökkenő trendet mutatott (Golovics és Zsinkó, 2021), de egy speciális orvosmintán végzett vizsgálatában Varga (2020) még így is azt találta, hogy 2009 és 2017 között a mintában szereplők körülbelül 6\%-a hagyta el az országot. Mindezt összevetve a hivatkozott munkaerőhiányról szóló adatokkal a helyzet továbbra is aggasztónak tekinthető, különösen az egyre inkább elhúzódó világjárvány árnyékában. Így az az egészségügyi béremelési intézkedés, amelyet a kormányzat 2020-ban jelentett be, többek között egy erre adott válaszként is értelmezhető. Golovics és Zsinkó (2020), Győrffy et al. (2018), Hárs és Simon (2016), illetve Varga (2016) elemzései ugyanis rámutattak arra, hogy a kedvezőtlen munkakörülmények, a kiégés, illetve a megbecsültség és a biztató előre jutási lehetőségek hiánya mellett az alacsony bérek is fő motivációt jelentenek az elvándorlásra a magyar orvosok és orvostanhallgatók körében. 
Jelen tanulmányban a külföldi munkavállalást tervező magyar állampolgárságú orvosok célország-preferenciáira fókuszálunk. Ezek 2010 és 2019 közötti alakulásának bemutatása mellett azt vizsgáljuk, hogy azonosíthatók-e valamilyen mintázatok a célország-preferenciákban bizonyos szociodemográfiai jellemzők - így a potenciális elvándorló kora, neme, lakhelye és szakvizsga-típusa - szerint. Tanulmányunkban tehát nem az elvándorlás motivációit, vagy befolyásoló tényezőit kívánjuk feltárni (erről lásd a fent hivatkozott irodalmakat), hanem azt, hogy a külföldi munkavállalás mellett már valamilyen szinten elköteleződött orvosok milyen mintázat szerint választanak célterületet. Ez a vetület ugyanis a korábbi irodalmakban nem képezte részletes elemzés tárgyát, noha az orvos-elvándorlás okozta közpolitikai probléma megértéséhez és az arra adható adekvát válaszok megértéséhez ennek megismerése szintén elengedhetetlen. Az elemzéshez az Állami Egészségügyi Ellátó Központ' [ÁEEK] (2020) által rendelkezésünkre bocsájtott adatokat használjuk, melyek az általuk kiadott, külföldi munkavállaláshoz szükséges hatósági bizonyítványok számáról, illetve az igénylők karakterisztikumairól tartalmaznak információkat. A célország-preferenciák és a szociodemográfiai jellemzők közötti kapcsolatot kereszttáblák elemzésével, függetlenségvizsgálat elvégzésével és az asszociációs kapcsolat mérésével teszteljük. Az adatok következő fejezetben tárgyalandó természetéből fakadó korlátozott statisztikai módszertani eszköztár tükrében azonban célunk elsősorban nem az oksági kapcsolatok tesztelése, hanem a trendek exploratív jellegü feltárása. A korábban nyilvánosan nem ismert adatok segítségével kívánjuk az egyes célországokra vonatkozó mintázatokat bemutatni és a keresletoldali hatások fényében kontextusba helyezni.

Tanulmányunk jelen bevezetését követően három további szerkezeti egységből áll. Előbb az elemzéshez használt adatok jellemzőit, főbb leíró statisztikáit tekintjük át, amit később a szociodemográfiai karakterisztikumok szerinti bontások tárgyalása követ. A tanulmányt végül a konklúziók összegzésével zárjuk.

${ }^{1}$ Az adatok rendelkezésre bocsájtása óta történt átszervezések révén: Országos Kórházi Főigazgatóság [OKFŐ]. 


\section{ADATOK: POTENCIÁLIS ELVÁNDORLÓ ORVOSOK ÉS CÉLORSZÁGAIK}

A kivándorolni szándékozó magyar orvosok a vizsgált időszakban az Állami Egészségügyi Ellátóközponttól (ÁEEK) tudták igényelni a szakképesítésükről szóló, külföldi munkavállaláshoz szükséges hatósági bizonyítványt. Tanulmányunkban ezen hatósági bizonyítványokról szóló adatokat használjuk, melyeket az ÁEEK (2020) bocsátott rendelkezésünkre kereszttáblás formában. ${ }^{2}$ Részben ilyen hatósági bizonyítvány-igénylési adatok segítségével adott képet a korábbi trendekről Balázs (2012), Girasek et al. (2013), illetve Boros és Pál (2016). Ugyancsak ezen - a jelen tanulmányéval is megegyező - adatbázis segítségével tekintette át a 2010-től 2019-ig tartó időszak főbb jellemzőit Golovics és Zsinkó (2021) munkája, amely azonban a célország-preferenciákról csak rendkívül korlátozottan szólt (mindössze a négy fő desztináció tíz éves összesitett adatát közölte). Mivel azonban a célország-választás az orvostársadalmon belül is eltérő mintázatokat mutathat, ezért ezek feltárása a jelenség mélyebb természetének a megértéséhez, vagy adott esetben akár a kiáramlás fékezéséhez is hozzájárulhat, ezért indokoltnak látjuk ennek részleteit külön tanulmányban tárgyalni. Ezért most kifejezetten a célország-preferenciák bemutatását helyezzük fókuszba, valamint a különböző szociodemográfiai jellemzők szerinti megoszlások elemzésére vállalkozunk.

Az általunk használt statisztikák migrációs potenciál adatok, azon belül tisztított migrációs potenciál mutatókként értelmezhetők (Sik, 2003). A hatósági bizonyítvány igényléséből ugyanis nem következik a tényleges elvándorlás, csupán az arra vonatkozó szándékot jelzi. Mindazonáltal, ez egy erősebb elköteleződést jelent, hiszen az igénylés leadásával az érintett orvos már konkrét lépést tesz a kivándorlás irányába. Tekintve továbbá, hogy döntő többségük megjelöli azt az országot, ahol a bizonyítványt fel szeretné használni, elmondható, hogy az igénylőknek általában a migrációs célra vonatkozóan konkrét elképzelésük van.

A hatósági bizonyítvány igénylése tehát szükséges, de nem elégséges feltétele a külföldi munkavállalásnak. Így ezen statisztikák a tényleges elvándorlás

\footnotetext{
${ }^{2}$ Az ÁEEK (illetve jelenleg az OKFŐ) bizonyos aggregált adatokat a honlapján is közölt, illetve az igénylőkre vonatkozó egyéni szintű adatokat szintén tárolták. Utóbbiak felhasználása természetesen mélyebb elemzésre adna teret, így az oksági kapcsolatok alaposabb megértését is lehetővé tenné. Ezek kikérésére korábban még volt lehetősége a kutatóknak (lásd például Hárs és Simon, 2016). Jelen tanulmány készítésekor azonban, az azóta hatályba lépő GDPR rendeletre, és az ennek nyomán megjelenő adatvédelmi szempontokra hivatkozva a szervezet ezen mikro-adatokat nem bocsátotta rendelkezésünkre.
} 
lehetséges mértékéről csak felső becslést tudnak adni. Az igénylők jellemzőinek rögzítése révén azonban a potenciális migráns orvosok összetételéről, valamint az áramlások potenciális irányairól komplex képet mutatnak. Ráadásul az adatok aszerint is szürhetők, hogy az igénylők között hányan voltak olyanok, akik a hatósági bizonyítvány kiállítását követő év áprilisa és decembere között nem jelentek meg vényfelíróként a magyar egészségügyi ellátórendszerben (a továbbiakban: vényfelíróként meg nem jelenők). Így képet kaphatunk egy olyan szűkebb csoportról, akik legnagyobb valószínüség szerint - legalább a szóban forgó időszakra - ténylegesen elhagyták az országot.

1. ábra: A külföldi munkavállaláshoz szükséges hatósági bizonyittányt igényelt magyar állampo/gárságú orvosok éves száma, 2010-2019

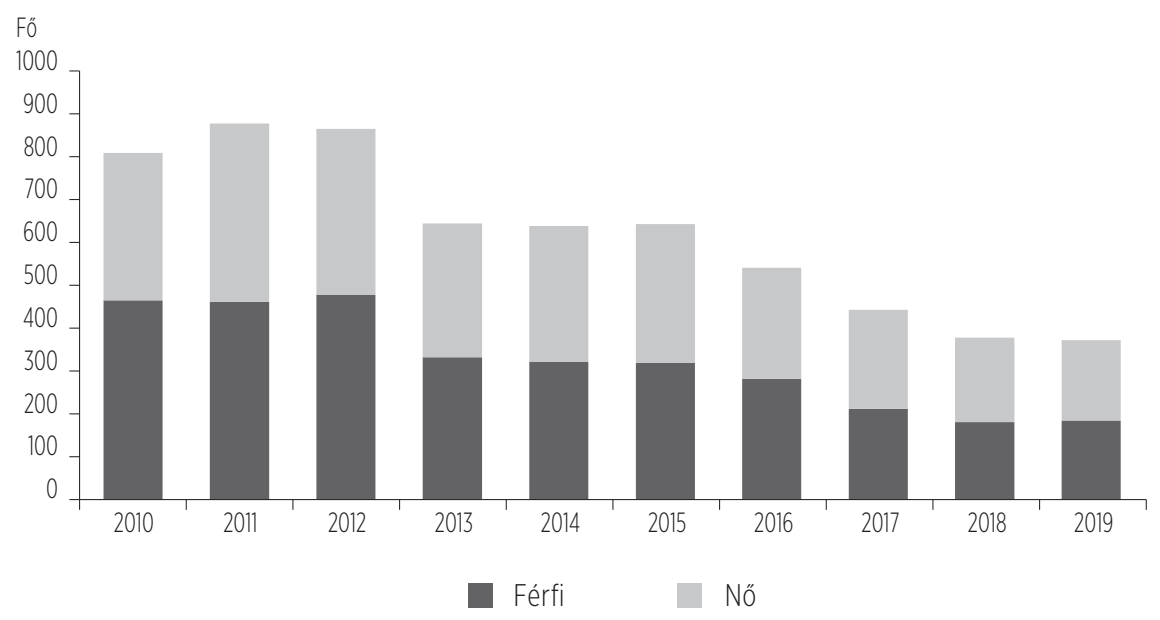

Forrás: Saját szerkesztés ÁEEK (2020) alapján.

A 2010 és 2019 közötti időszakban az ÁEEK összesen 6210 hatósági bizonyítványt állított ki magyar állampolgárságú orvosok számáraª , melyeknek évenkénti alakulásáról - nemek szerinti bontásban - az 1. ábra ad áttekintést. Az ábra jól látható csökkenő trendet mutat az évtized végéhez közeledve, ami nem csak a migrációs kedv mérséklődésére utalhat, hanem arra is, hogy a korábban kivándorolni szándékozó és arra képes orvosok ténylegesen megvalósíthatták ezen terveiket (vö. Varga, 2020 korábban hivatkozott tanulmányával).

\footnotetext{
3 Vizsgálatunk a fogorvosokra, gyógyszerészekre és a további szakdolgozókra - akik szintén az ÁEEK-tól igényelhettek hasonló hatósági bizonyítványt -, továbbá a Magyarországon képesítést szerzett külföldi állampolgárokra nem terjed ki.
} 
Ezt erősíti meg az is, hogy a 2010-2018-as időszak igénylőinek 64\%-a (3 738 fő) a bizonyítvány kiállítását követő év jelzett időszakában nem jelent meg vényfelíróként a magyar egészségügyben (a visszatérésről szóló információk hiányában azonban ezen adatok a ténylegesen külföldön tartózkodók állományáról csak durva felső becslést képesek adni). ${ }^{4}$

E 10 év alatti összes igénylő között rendre 48, illetve 52\%-ban találhatunk nőket és férfiakat. Kiemelendő, hogy 64\%-uk 40 év alatti volt, s közülük is a legtöbben (1 628 fő) a 25-29 éves korcsoportba tartoztak. Ez az utánpótlásbiztosítás és az orvosszakma elöregedése szempontjából tekinthető aggasztónak, különösen az utóbbi adatot tekintve, amely azt jelzi, hogy sokan már közvetlenül a diplomaszerzést követően a külföldi pályakezdésben gondolkodnak. A lakhely szerinti megosztást tekintve a legtöbben Budapestről (1 983 fő), illetve az orvosi egyetemek megyéiből (Pest 548 fö, Hajdú-Bihar 491 fő, Csongrád 408 fő, Baranya 364 fő) igényeltek hatósági bizonyítványt. A szakvizsgák típusa kapcsán az mondható el, hogy a legjobban érintett területek a belgyógyászat (498 fő), a háziorvostan (420 fő), valamint az aneszteziológia és intenzív terápia (417 fő) voltak, de sokan (az összes igénylő több, mint egy negyede) már a szakvizsga megszerzése előtt tervezték a külföldre távozást.

A célország-preferenciák vizsgálatát az teszi lehetővé, hogy - mint arra már utaltunk - a potenciális migráns orvosok a hatósági bizonyítvány igénylésekor megjelölhetik, mely célországban kívánják felhasználni azt. Noha ez opcionális, sőt magára a bizonyítványra sem kerül rá, így az máshol is felhasználható, a vizsgált időszak igénylőinek csak 1 ezreléke nem tette ezt meg.

A potenciális migráns orvosok legfőbb célországai a 10 év összesítésében Németország (1 855 fő), az Egyesült Királyság (1 572 fő), Ausztria (612 fő), Svédország (461 fő), Svájc (315 fő), Írország (290fő) és Románia (230 fő) voltak. Az, hogy a külföldi munkavállalást tervező orvosok a hatósági bizonyítvány igénylésekor ezen országokat jelölték meg a legnagyobb arányban, az általános migrációs elméletek implikációin (Massey et al., 1993) és az orvosok korábban hivatkozott elvándorlási motivációin túl a keresleti oldal, azaz a fogadó országok bizonyos empirikus jellemzőivel egyaránt magyarázható.

Mindenekelőtt kiemelhető, hogy az orvosok célország-preferenciái összhangban vannak a teljes népességre vonatkozó kivándorlók választásával. A bizonyítványt igénylők 65\%-a ugyanis az első három helyen szereplő országban tervezett munkát vállalni, amelyek a társadalom egészét tekintve is a legtöbb

${ }^{4}$ Arról, hogy a 2019-es év igénylői közül 2020-ban hányan jelentek meg vényfelíróként a magyar egészségügyben, a kézirat készitésekor még nem állt rendelkezésünkre információ. 
magyar állampolgárságú rezidenst tartják számon (Eurostat, 2021). A potenciális elvándorló orvosok számára tehát a migrációs hálózatok (Massey et al., 1993) megléte is megkönnyíthette mind a kijutást és mind a beilleszkedést. Emellett a teljes gazdaságra egyaránt jellemző bérszínvonalbeli szakadék az Organisation for Economic Co-operation and Development OECD (2021) adatai szerint az egészségügyi szektorban ugyancsak erőteljesen jelen van Keletés Nyugat-Európa között. Az általános orvosok Németországban az átlagbér közel négy és félszeresét, Ausztriában több, mint háromszorosát, az Egyesült Királyságban pedig akár 3,3-szeresét is megkereshetik, szemben a hazai másfélszeres szorzóval. Szintén fontos jellemzője ezen célországoknak, hogy orvosképzésük alacsonyabb kibocsátással dolgozik a hazainál: a százezer före vetített végzett orvostanhallgatók száma mindhárom esetében alacsonyabb, mint Magyarországon. Figyelembe véve az országok demográfiai jellemzőit, ez egy igen erőteljes keresletet generálhat a külföldi orvosok irányába, mely leginkább az Egyesült Királyság egészségügyében látható jelenleg is, ahol a külföldön végzett orvosok aránya - jóval az OECD-átlagot meghaladva - eléri a harminc százalékot (ami arra utal, hogy a jelenségnek egyfajta kultúrája van). Az egyes célországok szerkezeti jellemzőit tovább vizsgálva az is elmondható, hogy Németországban rendkívül magas, Ausztriában az OECD-átlagot alulról közelítő, az Egyesült Királyságban pedig kiugróan alacsony az 55 évnél idősebb orvosok aránya (OECD, 2021). Ez alapján azt várhatjuk, hogy előbbi célország egészségügye inkább a fiatal, míg utóbbié jellemzően a tapasztaltabb szakemberek iránt támaszthat erősebb keresletet. Mindezek figyelembevétele mellett ugyanakkor aggasztó tény, hogy a vizsgált időszakban - egy-egy negyedév kivételével - a fő célországokban a magyarországinál rendre alacsonyabb volt a betöltetlen álláshelyek aránya a humánegészségügy és szociális ellátás területén (Eurostat, 2022a). Igaz, az Egyesült Királyság és Németország értékei ezen indikátor mentén a tíz év viszonylatában általában magasabbak voltak, mint ami Nyugat-Európa - a hazainál magasabb bérszínvonallal rendelkező - országaira jellemző. Ez pedig adalékkal szolgálhat a két célország szívó hatásának magyarázatához. Fontos továbbá kiemelni, hogy a célterületválasztást az Egyesült Királyság esetén az angol nyelv vonzereje, Németországot és Ausztriát illetőleg pedig a földrajzi közelség, illetve a történelmi-kulturális kapcsolatok is befolyásolhatták.

A többi célország esetében ugyancsak azonosithatók bizonyos, keresletet befolyásoló motívumok. A Svédország és Írország iránti érdeklődés inkább az évtized első éveiben volt jelentősebb, ami azzal magyarázható, hogy a 2004-es bővítést követően az Egyesült Királyság mellett ezen országok nyitották meg teljesen a munkaerőpiacaikat az új tagállamok polgárai előtt. Ezzel összefüggésben 
látható, hogy mindkét országban kiemelkedően magas a külföldön végzett orvosok aránya (OECD, 2021). A német és osztrák moratóriumok feloldása után, az évtized második felében azonban a magyar orvosok is relative alacsonyabb vándorlási hajlandóságot mutattak az irányukba. Az Írország iránti érdeklődés csökkenése emellett azzal is magyarázható, hogy az elmúlt két évtizedben az ország jelentősen megduplázta a frissen végzett orvosainak számát, amivel 2019-ben OECD-viszonylatban népességarányosan már a legmagasabb értéket produkálta (OECD, 2021). Svájc népszerüsége - figyelembe véve az orvos-elvándorlásnak az áttekintett irodalmakban nevesített motivációit - elsősorban az anyagi tényezőkkel magyarázható: az általános gazdasági mutatók mellett az OECD (2021) adatai szerint az ország mind abszolút mértékben, mind GDP-arányosan rendkívül sokat költ az egészségügyre, ami nem csak a magas bérekben, hanem a kedvező munkahelyi adottságok és minőségi mutatók tekintetében is érezteti hatását. Utóbbiak - figyelembe véve a relatíve visszafogottabb, OECD-átlag alatti kibocsátású orvosképzést is - ugyancsak vonzerővel bírhatnak a külföldi orvosokra, amelynek eredményeként arányuk rendkívül magas (36\%) az országban. A főbb célországok listájában egyetlen kelet-közép-európai országként Románia tekinthető „kakukktojásnak”, igaz, előkelő helyezését az ország leginkább csak a 2019-es kiugróan magas értéknek köszönheti. Mindazonáltal Romániát vélhetően a magyar állampolgársággal is rendelkező, határon túlról érkező, s oda a diploma megszerzését követően visszatérni kívánó magyarok jelölhették meg.

Az európai célországok tíz éves viszonylatra vonatkozó megjelölési adatait a 2. ábra szemlélteti, míg az Európán kívüli területekről az 1. melléklet ad áttekintést. Az előzőekben tárgyalt, kiemelt célországokat megjelölő potenciális migráns orvosok számának évenkénti alakulását pedig az 1. táblázatban összegezzük. Mint látható, a célországok „,népszerüségi rangsorában” voltak minimális különbségek az évek között, de a nagyságrendek és az arányok erőteljesen nem változtak. Egyetlen tényező emelhető csak ki, méghozzá az, hogy az első két helyen álló Németország és Egyesült Királyság nagymértékű dominanciája az évtized végére csökkent a megjelölési arányok tekintetében.

A célország-preferenciák azon orvosok körében is hasonlóan alakultak, akik a bizonyítvány igénylését követő év áprilisa és decembere között nem jelentek meg vényfelíróként a magyar egészségügyben. Az egyetlen különbséget az jelentette, hogy ebben a körben a hetedik legnépszerúbb célország Norvégia volt 2010 és 2018 között, míg Románia - a 2019-es adatok hiányában - csak a tizenkettedik helyen szerepelt. Ezt leszámítva a többi fogadó ország, azok sorrendje, illetve a hozzávetőleges megjelölési arányok is megegyeznek a fent tárgyaltakkal. 
2. ábra: A külföldi munkavállaláshoz szükséges hatósági bizonyitványt igényelt magyar állampolgárságú orvosok száma célországok szerint (európai célországok, 2010-2019)

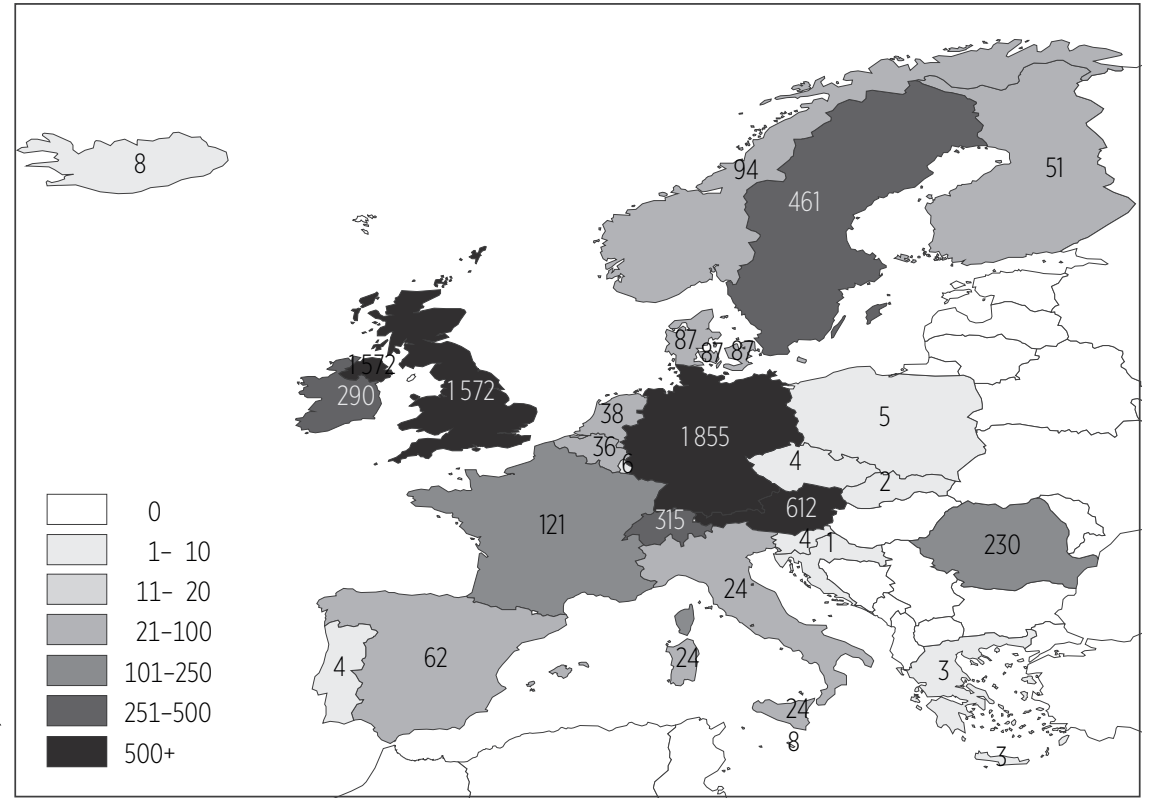

Forrás: Saját szerkesztés ÁEEK (2020) alapján.

1. táblázat. A fö célországpreferenciák alakulása a potenciális migráns orvosok körében, 2010-2019 (fö és megoszlási arány zárójelben)

\begin{tabular}{lrrrrrrrrrrr} 
Célország & 2010 & 2011 & 2012 & 2013 & 2014 & 2015 & 2016 & 2017 & 2018 & 2019 & $\begin{array}{c}\text { Össze- } \\
\text { sen }\end{array}$ \\
\hline Német- & 244 & 325 & 327 & 223 & 198 & 172 & 132 & 89 & 75 & 70 & 1855 \\
ország & $(36 \%)$ & $(41 \%)$ & $(43 \%)$ & $(40 \%)$ & $(35 \%)$ & $(31 \%)$ & $(29 \%)$ & $(24 \%)$ & $(25 \%)$ & $(23 \%)$ & $(35 \%)$ \\
Egyesült & 270 & 283 & 213 & 162 & 137 & 152 & 114 & 88 & 85 & 68 & 1572 \\
Királyság & $(40 \%)$ & $(36 \%)$ & $(28 \%)$ & $(29 \%)$ & $(24 \%)$ & $(27 \%)$ & $(25 \%)$ & $(24 \%)$ & $(28 \%)$ & $(23 \%)$ & $(29 \%)$ \\
Ausztria & 46 & 48 & 80 & 52 & 75 & 83 & 65 & 66 & 57 & 40 & 612 \\
& $(7 \%)$ & $(6 \%)$ & $(11 \%)$ & $(9 \%)$ & $(13 \%)$ & $(15 \%)$ & $(14 \%)$ & $(18 \%)$ & $(19 \%)$ & $(13 \%)$ & $(11 \%)$ \\
Svéd- & 39 & 71 & 76 & 67 & 51 & 61 & 44 & 22 & 16 & 14 & 461 \\
Ország & $(6 \%)$ & $(9 \%)$ & $(10 \%)$ & $(12 \%)$ & $(9 \%)$ & $(11 \%)$ & $(10 \%)$ & $(6 \%)$ & $(5 \%)$ & $(5 \%)$ & $(9 \%)$ \\
Svájc & 14 & 11 & 24 & 25 & 37 & 40 & 38 & 56 & 40 & 30 & 315 \\
& $(2 \%)$ & $(1 \%)$ & $(3 \%)$ & $(5 \%)$ & $(7 \%)$ & $(7 \%)$ & $(8 \%)$ & $(15 \%)$ & $(13 \%)$ & $(10 \%)$ & $(6 \%)$ \\
Írország & 51 & 50 & 31 & 17 & 35 & 18 & 35 & 27 & 10 & 16 & 290 \\
& $(7 \%)$ & $(6 \%)$ & $(4 \%)$ & $(3 \%)$ & $(6 \%)$ & $(3 \%)$ & $(8 \%)$ & $(7 \%)$ & $(3 \%)$ & $(5 \%)$ & $(5 \%)$ \\
Románia & 19 & 9 & 10 & 7 & 29 & 31 & 24 & 20 & 21 & 60 & 230 \\
& $(3 \%)$ & $(1 \%)$ & $(1 \%)$ & $(1 \%)$ & $(5 \%)$ & $(6 \%)$ & $(5 \%)$ & $(5 \%)$ & $(7 \%)$ & $(20 \%)$ & $(4 \%)$
\end{tabular}

Megjegyzés: A zárójelben feltüntetett megoszlási arányok az egyes éveken belüli megoszlást mutatják a célországok között.

Forrás: Saját szerkesztés ÁEEK (2020) alapján. 
A célország-preferenciák azon orvosok körében is hasonlóan alakultak, akik a bizonyítvány igénylését követő év áprilisa és decembere között nem jelentek meg vényfelíróként a magyar egészségügyben. Az egyetlen különbséget az jelentette, hogy ebben a körben a hetedik legnépszerübb célország Norvégia volt 2010 és 2018 között, míg Románia - a 2019-es adatok hiányában - csak a tizenkettedik helyen szerepelt. Ezt leszámítva a többi fogadó ország, azok sorrendje, illetve a hozzávetőleges megjelölési arányok is megegyeznek a fent tárgyaltakkal.

A hat legnépszerübb célország esetén a 3. ábra szemlélteti, hogy tíz év viszonylatában a hatósági bizonyítványt igénylők mekkora része jelent meg a következő évben vényfelíróként a hazai egészségügyben. Mint látható, Németország és Svájc esetében a potenciális elvándorlóknak több, mint a fele Magyarországon is jelen volt vényfelíróként, így ők vagy nem valósították meg migrációs szándékukat, vagy azt csak rövidebb időszakra, esetleg ingázva tették meg. Ausztriában azonban - ahol a földrajzi közelség miatt az ingázás még könnyebben megvalósítható, s aminek lehetőségével a teljes népesség munkavállalói is gyakran élnek (Kovács és Sipos, 2020) - ez az arány csak 35\%. Ezzel szemben az Egyesült Királyságot, Svédországot és Írországot illetően drasztikusan eltérő adatokat figyelhetünk meg. Ebből arra következtethetünk, hogy akik e célországokban terveztek munkát vállalni, azok nagyrészben sikeresen megvalósították terveiket.

3. ábra: A vényfeliróként meg nem jelenő hatósági bizonyitványt igényelt magyar állampolgárságú orvosok száma a föbb célországok szerint, 2010-2019

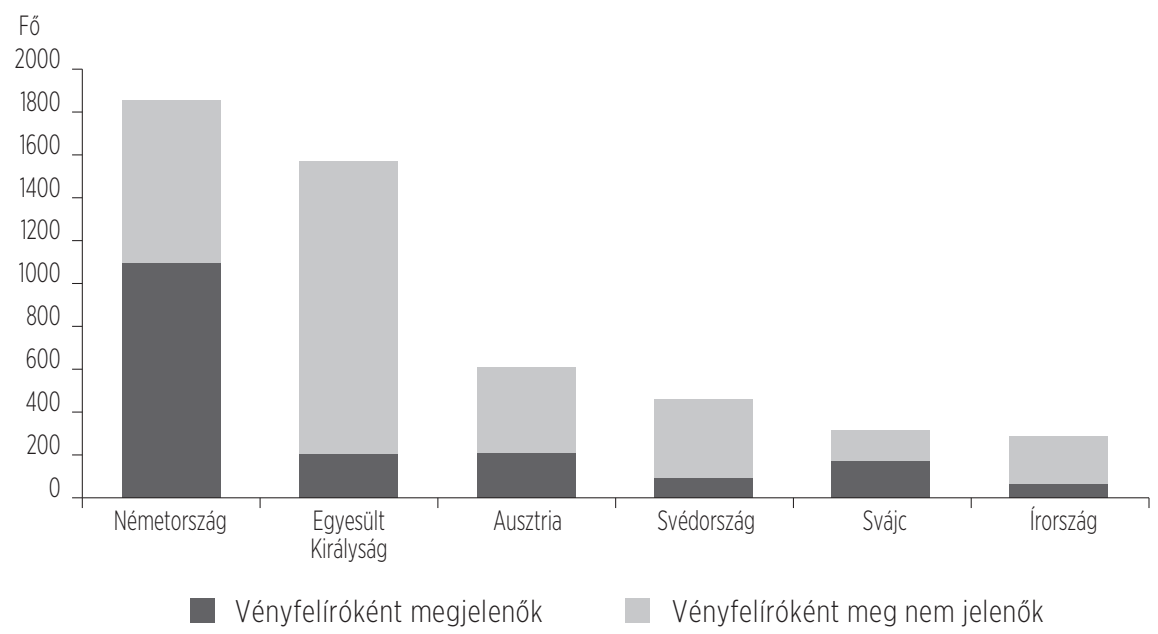

Forrás: Saját szerkesztés ÁEEK (2020) alapján. 


\section{CÉLORSZÁG-PREFERENCIÁK: KIK ÉS HOVA?}

A továbbiakban az előző fejezetben bemutatott adatok felhasználásával vizsgáljuk meg, hogy az egyes célországokba az orvosok mely szociodemográfiai csoportjai terveztek kivándorolni, továbbá felfedezhető-e valamilyen mintázat a migrációs szándékokban. Mivel a változóink nominális, illetve ordinális skálán mérhetőek, így a közöttük lévő kapcsolat létét függetlenségvizsgálat segítségével teszteljük. Ehhez először kereszttáblák használatával szemléltetjük az adatok kategóriánkénti megoszlását, majd a dimenziók közötti függetlenséget $x^{2}$-próbával vizsgáljuk. A függetlenség elvetése esetén Cramer-féle asszociációs együtthatóval (V) mérjük a kapcsolat erősségét. A vizsgálatokat rendre elvégezzük a hatósági bizonyítványt igénylő összes orvos, valamint a vényfelíróként meg nem jelenők csoportjára is.

A kereszttáblák egyik dimenzióját a megjelölt célországok, a másikat pedig rendre a bizonyítványt igénylők neme, korcsoportja, lakhelye, valamint szakvizsgájának típusa képezi. Az elemzésbe a tíz éves viszonylatban legnépszerübb hat célországot vonjuk be, mivel ez volt az a kör, amely megegyezett mind az öszszes igénylő, mind a vényfelíróként meg nem jelenők között. Ezzel a vizsgálati körbe vont minta az összes igénylőnél, illetve a vényfelíróként meg nem jelenőknél rendre 5 105, illetve 3252 főt számol, amelyek a teljes sokaságok 82, illetve 87\%-át teszik ki. Amikor a szakvizsga-típusokat vizsgáljuk, akkor a 10 leginkább érintett szakterületet vonjuk be a vizsgálati körbe, amellyel az előbbi minták a vonatkozó kereszttáblák esetében rendre 2 388, illetve 1289 före csökkennek.

A fő célországok megjelölésének nemek szerinti megoszlását a 2. táblázat szemlélteti. Mint látható, a hat fő célországot megközelítőleg hasonló arányokban jelölték meg mindkét nem képviselői, és csupán kisebb eltérések figyelhetők meg. Németország és Svájc inkább a nők (előbbit az összes kivándorlást tervező orvosnő 40 százaléka jelölte meg célként), míg az Egyesült Királyság és Írország inkább a férfiak körében mutatkozott népszerübbnek. Előbbieket nézve az arányok az ÁEEK (2020) - a táblázatban nem részletezett - adatai alapján az egyes években is többnyire stabilnak mutatkoztak, ám az Egyesült Királyság esetén az évtized eleji jelentősebb férfi-többlet eltűnt, míg Írországot tekintve az évenként változó arányok eredőjeként állt elő ez az eredmény. Svédországot nézve azonban végig viszonylag kiegyenlített volt a nemi arány, míg Ausztriában kezdetben inkább a férfiak terveztek munkát vállalni, ám az évtized második felében a nők is „felzárkóztak” hozzájuk. Tekintve, hogy az OECD (2021) adatai szerint az egyes célországok orvosállományában nincsenek igazán kiugró - az 50-50 százalékos aránytól jelentősen eltérő - értékek a nemi arányok tekinte- 
tében, így érdemi keresleti hatásokról sem beszélhetünk. Egyedüli kivételként Svájc említhető: itt ugyanis a női orvosok aránya az ezredfordulón még 30\% alatt volt, ám ez az arány 2019-re 43\%-ra nőtt. Ez pedig magyarázatul szolgálhat arra, hogy az ország egészségügye a magyar orvosok közül is inkább a nők irányába mutathatott jelentősebb keresletet. Így összességében, bár a két dimenzió függetlenségét 1\%-os szignifikancia szinten elvethetjük ugyan, a Cramer-mutató 0,10-es értéke csak gyenge kapcsolatot jelez.

2. táblázat. A potenciális migráns orvosok száma a fó célországok és nemek szerinti bontásban, 2010-2019 (fö és megoszlási arány zárójelben)

\begin{tabular}{|c|c|c|c|c|c|c|}
\hline \multirow{2}{*}{$\begin{array}{c}\text { Célország } \\
\text { Németország }\end{array}$} & \multicolumn{2}{|c|}{ Férfi } & \multicolumn{2}{|c|}{ Nő } & \multicolumn{2}{|c|}{ Összesen } \\
\hline & $\begin{array}{r}865 \\
(33 \%)\end{array}$ & $(47 \%)$ & $\begin{array}{r}990 \\
(40 \%)\end{array}$ & $(53 \%)$ & $\begin{array}{l}1855 \\
(36 \%)\end{array}$ & $(100 \%)$ \\
\hline Egyesült Királyság & $\begin{array}{r}897 \\
(34 \%)\end{array}$ & $(57 \%)$ & $\begin{array}{r}675 \\
(27 \%)\end{array}$ & $(43 \%)$ & $\begin{array}{l}1572 \\
(31 \%)\end{array}$ & $(100 \%)$ \\
\hline Ausztria & $\begin{array}{r}318 \\
(12 \%)\end{array}$ & $(52 \%)$ & $\begin{array}{r}294 \\
(12 \%)\end{array}$ & $(48 \%)$ & $\begin{array}{r}612 \\
(12 \%)\end{array}$ & $(100 \%)$ \\
\hline Svédország & $\begin{array}{l}234 \\
(9 \%)\end{array}$ & $(51 \%)$ & $\begin{array}{r}227 \\
(9 \%)\end{array}$ & $(49 \%)$ & $\begin{array}{r}461 \\
(9 \%)\end{array}$ & $(100 \%)$ \\
\hline Svájc & $\begin{array}{l}139 \\
(5 \%)\end{array}$ & $(44 \%)$ & $\begin{array}{r}176 \\
(7 \%)\end{array}$ & $(56 \%)$ & $\begin{array}{l}315 \\
(6 \%)\end{array}$ & $(100 \%)$ \\
\hline Írország & $\begin{array}{l}162 \\
(6 \%)\end{array}$ & $(56 \%)$ & $\begin{array}{l}128 \\
(5 \%)\end{array}$ & $(44 \%)$ & $\begin{array}{l}290 \\
(6 \%)\end{array}$ & $(100 \%)$ \\
\hline Összesen & $\begin{array}{r}2615 \\
(100 \%)\end{array}$ & $(51 \%)$ & $\begin{array}{r}2490 \\
(100 \%)\end{array}$ & $(49 \%)$ & $\begin{array}{r}5105 \\
(100 \%)\end{array}$ & $(100 \%)$ \\
\hline
\end{tabular}

Megjegyzés: Az orvosok létszám-adatai alatt zárójelben szereplő százalékos értékek a nemen belüli célországonkénti megoszlást, míg az értékektől jobbra elhelyezkedő, zárójelben szereplő százalékos értékek a célországon belüli, nemi megoszlást mutaták.

Forrás: Saját szerkesztés ÁEEK (2020) alapján.

Ezen arányok alakulását a vényfelíróként meg nem jelenők körében a 2. melléklet tartalmazza. Az időbeli trendek alakulása kapcsán emelhetjük ki azt, hogy kezdetben inkább a férfiak által preferált Egyesült Királyság az évtized második felében a nők körében is egyre népszerübb célországgá vált. A nem és a célország-megjelölés függetlenségét elutasíthatjuk 1\%-os szignifikancia szinten, ám a Cramer-féle asszociációs együttható itt még alacsonyabb (0,07), ami elhanyagolható erősségű kapcsolatra utal. Így összességében megállapítható, hogy erőteljes mintázat a nem és a célországpreferenciák tekintetében nem rajzolódik ki.

A célország-megjelölések korcsoportok szerinti megoszlását a 3. táblázat szemlélteti. Ebben látható, hogy Ausztriát, Írországot, Svájcot és Svédországot 
megközelítőleg a mintában szereplő arányaiknak megfelelően választották az egyes korcsoportok, azzal a kitétellel, hogy utóbbinál a fiatal (30 év alatti) orvosok aránya relatíve alacsony volt. Emellett kiemelendő, hogy Svájc népszerübbé válása az évtized második felére egyértelműen a 35 év alatti orvosoknak „köszönhető” (ÁEEK, 2020). Ezzel szemben az Egyesült Királyságba - ahol az orvostársadalom OECD-összevetésben (2022) kimondottan fiatalnak mondható - relatíve inkább a már tapasztalattal rendelkező, 35 év feletti orvosok terveztek migrálni (ám a korcsoporti arányok az évtized végére jobbára itt is kiegyenlítődtek). Ami a fiatalabb korosztályt illeti, ők - az egyes években, s a tíz év összesítésében is - leginkább Németországban terveztek munkát vállalni. Figyelembe véve a korábban hivatkozott OECD-adatot (2021) az elöregedő német orvostársadalomról, a vonatkozó keresleti hatás bizonyára szerepet játszott. Mindezt tekintve a korcsoportok és a célország-választás közötti függetlenséget a $x^{2}$-próba alapján elvethetjük 1\%-os szignifikancia szinten, azonban a Cramermutató 0,15-os értéke ugyancsak gyenge kapcsolatra utal.

A vényfelíróként meg nem jelenőknél hasonló mintázat figyelhető meg a kor és a célországpreferenciák tekintetében. Az erre vonatkozó kereszttábla a 3. mellékletben található. A függetlenséget esetükben ugyancsak elvethetjük 1\%-os szignifikancia szinten, továbbá a Cramer-féle asszociációs együttható értéke $(V=0,17)$ szintén hasonló nagyságrendü.

A célországpreferenciák lakhely (megye) szerinti megoszlását a 4. táblázat tartalmazza. Bár a két dimenzió közötti függetlenséget a $x^{2}$-próba alapján 1\%-os szignifikancia szinten elutasithatjuk, a Cramer-féle asszociációs együttható értéke alacsony $(V=0,15)$, és az adatokban sem láthatók kiugró értékek. Az egyetlen kiemelendő tényező a földrajzi realitásokkal áll összefüggésben: a nyugati határhoz közel, a Győr-Moson-Sopron és Vas megyei orvosok az arányosan várható értékeknél jóval magasabb számban igényeltek hatósági bizonyítványt Ausztria megjelölésével.

A legtöbb igénylést számláló területekre, az orvosi egyetemek vonzáskörzeteire fókuszálva óvatosabb megállapítások tehetők. Az Egyesült Királyság az összes igényléshez viszonyítva relatíve a budapesti, valamint a Csongrád és Pest megyei orvosok körében volt népszerü, míg Németországban inkább a Baranya megyeiek terveztek munkát vállalni. Utóbbiak körében Svédország is aránylag népszerübbnek mutatkozott. A Hajdú-Bihar megyei orvosoknál azonban Ausztria nem bizonyult preferált desztinációnak, ám a többi célországot a sokasági arányokkal közel azonos mértékben jelölték meg. Ezenfelül a táblázatban nem részletezett ÁEEK (2020) adatok időbeli trendjeit vizsgálva egy-egy kiugró értéket láthatunk ugyan, érdemben beazonosítható mintázatot azonban nem. 


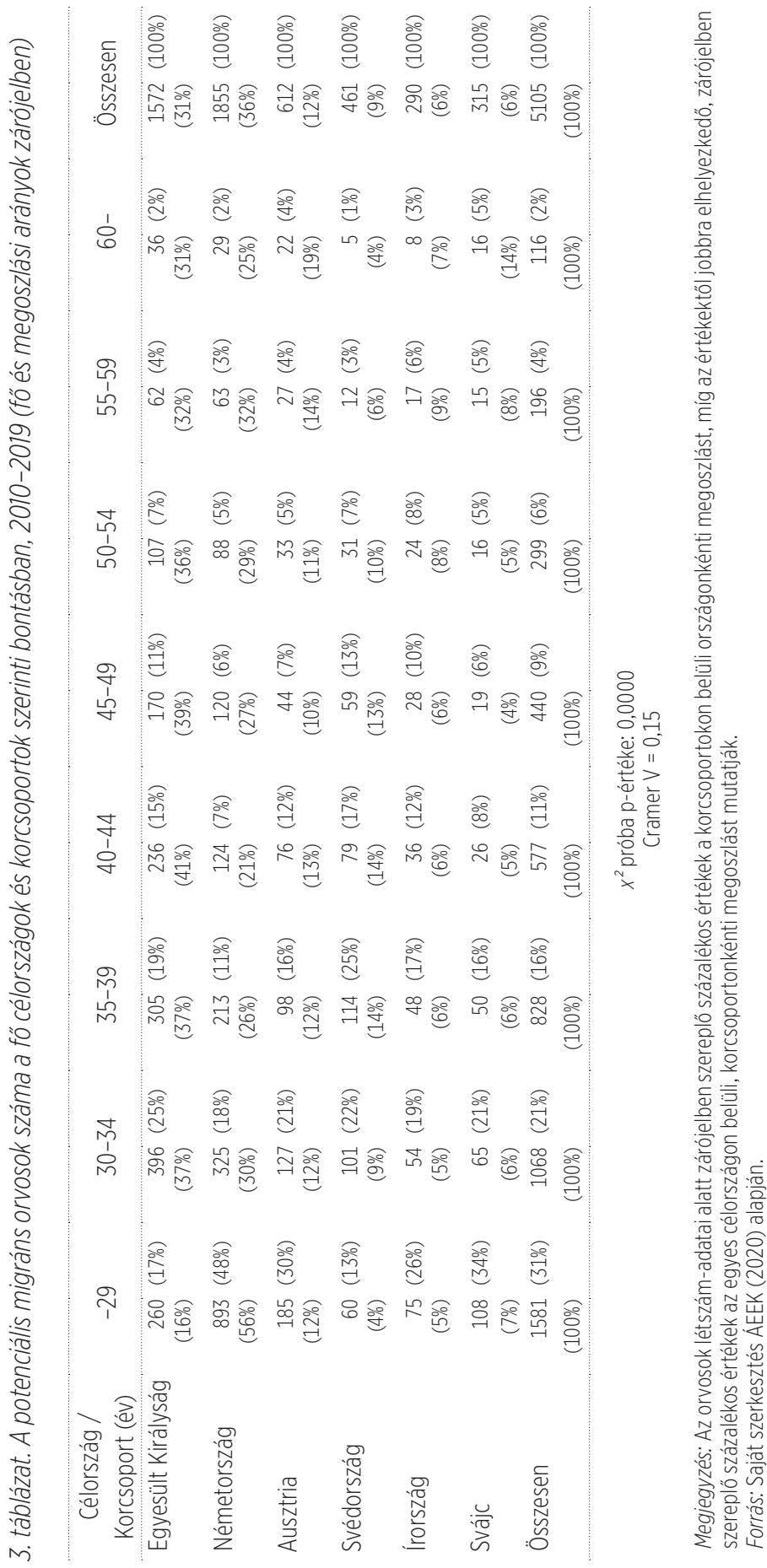




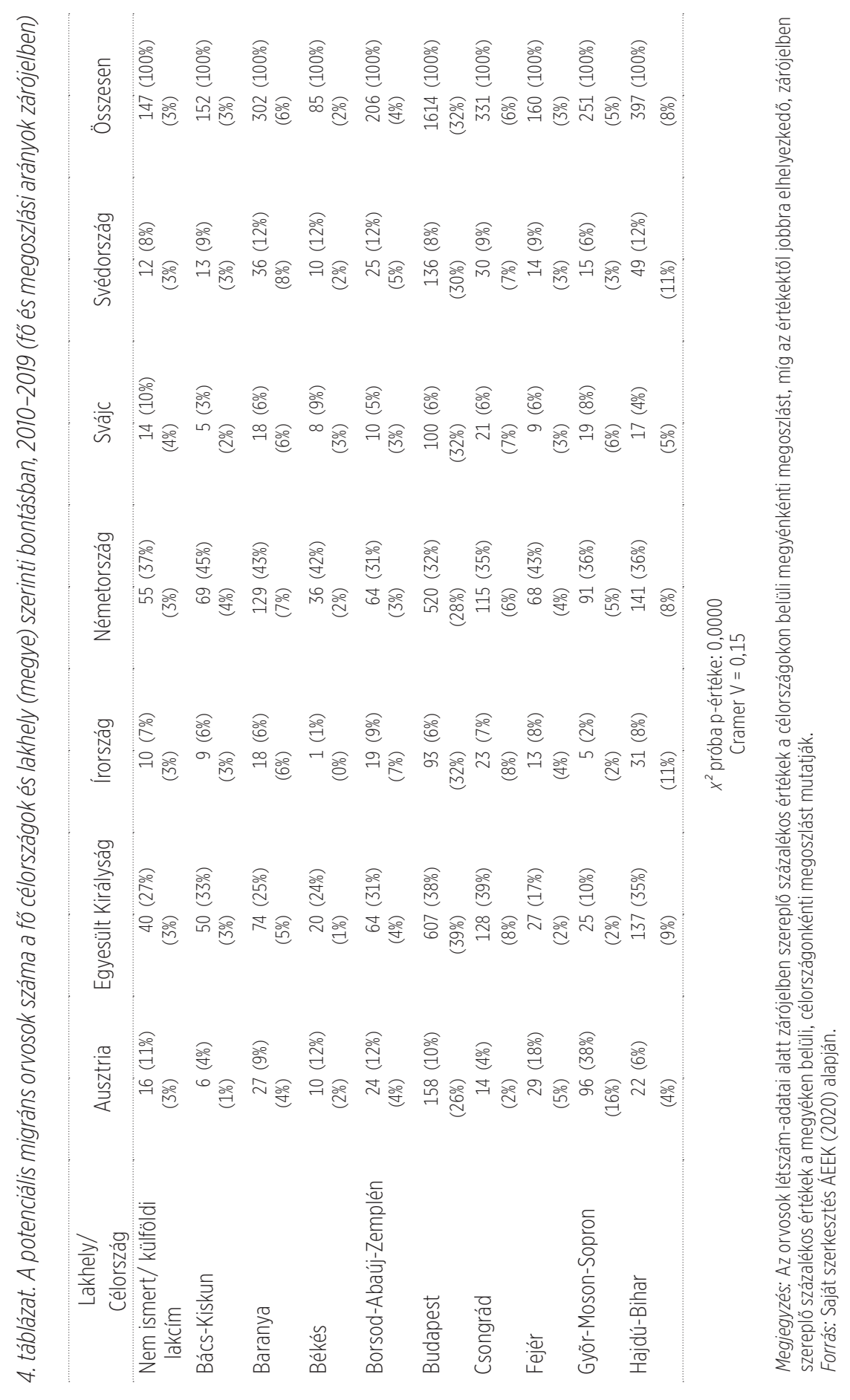




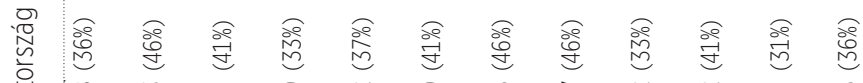
峁 少

:

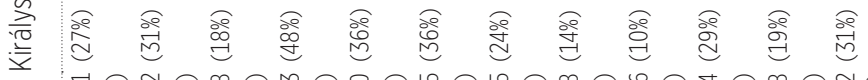
苞 
A vényfelíróként meg nem jelenők körében ugyancsak hasonló mintázat mutatkozik a lakhely szerinti célországpreferenciák tekintetében. Ezekről a 4. melléklet ad áttekintést. $\mathrm{A} x^{2}$-próba $\mathrm{p}$-értéke itt ugyancsak kisebb, mint 0,01, a Cramer-mutató $(V=0,15)$ pedig gyenge kapcsolatra utal. Az egyetlen kiemelendő szempont az, hogy Győr-Moson-Sopron és Vas megye Ausztriát megjelölő orvosainak számai ugyan szintén magasabbak, mint a függetlenség esetén elvárt gyakoriságok, ám jelentősen kisebb mértékben, mint az összes igénylőnél. Ez megerősitheti azt a feltevést, hogy ezen megyékből a földrajzi közelséget kihasználva többen rövid időre vagy ingázva, de a hazai praxist megtartva vállaltak munkát a szomszédos országban.

A föbb célországok és szakvizsga-típusok megoszlását az 5. táblázat foglalja össze. A függetlenséget a $x^{2}$-próba alapján elvethetjük 1\%-os szignifikancia szinten, ám a Cramer-mutató értéke $(V=0,18)$ úgyszintén alacsony. Az adatokból kitűnik, hogy Svédország - a sokasági arányokhoz mérten - rendkivül népszerű célpont volt mind a patológusok, illetve mind a pszichiáterek körében (jóllehet az Eurostat (2022b) elérhető adatai alapján e szakterületek az EU-s viszonyokhoz képest lakosságarányosan nem tekinthetők hiány-szakmának az országban). Előbbiek Írországot is relatíve gyakran jelölték meg célországként a hatósági bizonyítvány igénylésekor. Ausztriára inkább az aneszteziológusok, a sebészek és a szülész-nőgyógyászok tekintettek potenciális desztinációként, ami azért kiemelendő, mert az ország mindhárom területen kifejezetten jó lakosságarányos ellátottsággal rendelkezik (Eurostat, 2022b). Az Egyesült Királyságba, Németországba és Svájcba hozzávetőlegesen a sokasági arányoknak megfelelő mértékben terveztek kivándorolni az egyes területek képviselői. ${ }^{5}$

\footnotetext{
${ }^{5}$ Becsült számosságuk okán külön elemzést érdemelne a szakvizsgával nem rendelkezök célország-preferenciáinak vizsgálata, ezt azonban a rendelkezésre álló adatok nem teszik lehetővé. Az ÁEEK rendelkezésünkre bocsátott adatbázisa ugyanis nem tartja nyilván külön a szakvizsgával nem rendelkezö személyeket. Továbbá, mivel a hatósági bizonyitványigénylést az orvosok szakvizsga-típusonként adhatják le, és az egyes személyek több szakvizsgával is rendelkezhetnek, ezért a kívánt adat nem állitható elő egyszerủen az összes igénylőre, valamint a szakvizsgák számára vonatkozó adatok különbségeként.
} 
.

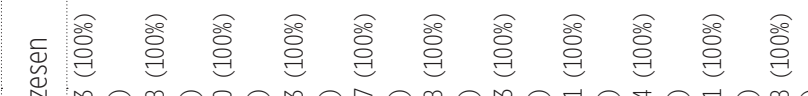

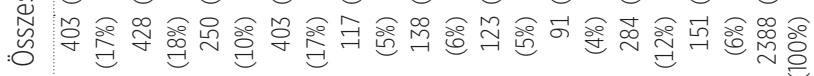

ว

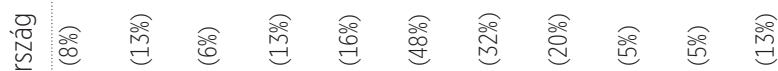

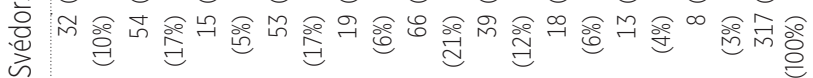

迟

$\stackrel{5}{5}$

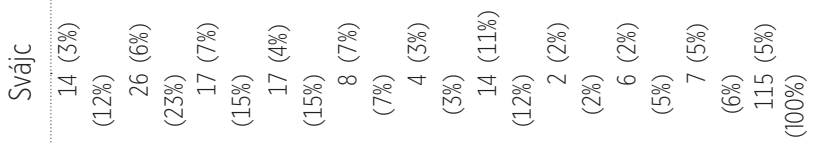

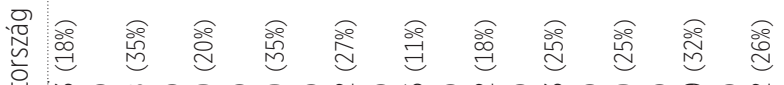

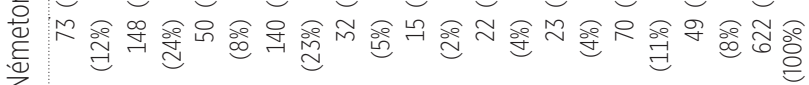

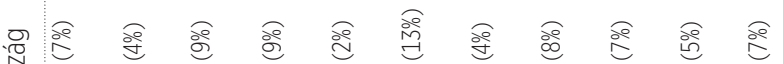

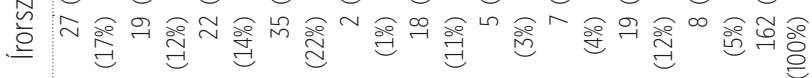

ए

究

品

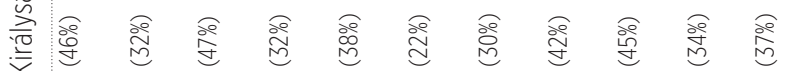

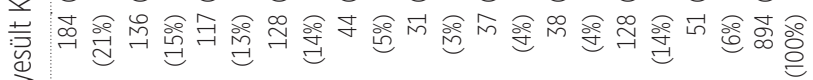

离

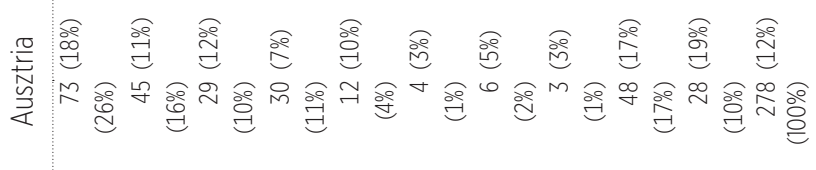

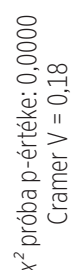

$\frac{0}{0}$
$\frac{d}{d}$
$\frac{d}{d}$
$\frac{2}{\bar{Q}}$

$\frac{\sqrt{\frac{0}{8}}}{\frac{2}{0}}$

产

$\frac{+2}{4}$

을

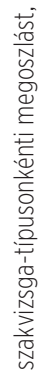

i

过

है

造

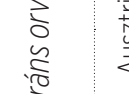

है

$\frac{\sqrt{2}}{\frac{\pi}{2}}$

¿
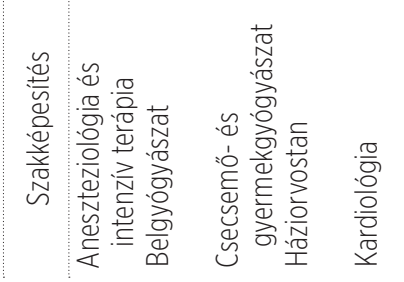

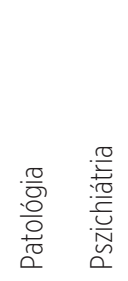
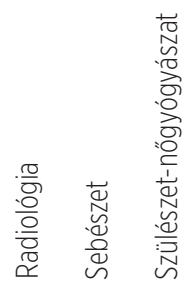

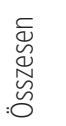

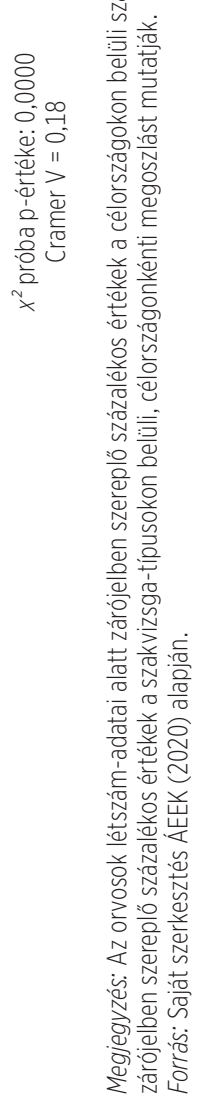


Ugyanez a mintázat tükröződik vissza - némiképp még erősebben - a vényfelíróként meg nem jelenő orvosok között (azzal a kiegészítéssel, hogy náluk jobban kidomborodik az Egyesült Királyság népszerüsége az aneszteziológusok körében). Ennek megfelelően a khí-négyzet próba alapján elutasíthatjuk a függetlenséget ( $p<0,01)$, a Cramer-mutató 0,23-os értéke pedig valamelyest magasabb az előző vizsgálatokban tapasztaltaknál. Ezen adatokról az 5. melléklet ad áttekintést.

\section{ÖSSZEGZÉS}

Tanulmányunkban az elvándorlást tervező magyar állampolgárságú orvosok célország-preferenciáit tekintettük át a 2010 és 2019 közötti időszakra vonatkozóan az Állami Egészségügyi Ellátó Központ által kiadott, külföldi munkavállaláshoz szükséges hatósági bizonyítványokra vonatkozó adatok alapján. Vizsgálataink eredményei azt mutatták, hogy statisztikai értelemben igazán erőteljes kapcsolat nem mutatkozik a kivándorolni szándékozó orvosok neme, korcsoportja, lakhelye és szakvizsgatípusa, illetve a célország-választásuk között. Mindazonáltal a tíz év adatai alapján néhány jellemző motívum egyértelműen kiemelhető. Ilyen például, hogy a 30 év alatti orvosok igen jelentős része Németországban tervez munkát vállalni, de említhető a nyugati határ melletti megyék orvosainak valószínűsíthető ingázása Ausztriába, vagy éppen a patológusok fokozott érdeklődése Svédország iránt.

Mindemellett az orvosokra vonatkozó statisztikákat a teljes népesség elvándorlóinak jellemzőivel is érdemes összevetni, különösen annak tükrében, hogy utóbbiak körében szintén Németország, az Egyesült Királyság és Ausztria számítanak a legkedveltebb célországoknak (a teljes népességre jellemző mintázatokról lásd Blaskó et al., 2014; Gödri, 2018). Noha mind a teljes magyar populáció elvándorlóinak, mind a migrációt tervező orvosok körében enyhe férfitöbblet figyelhető meg, az egyes célországok esetében már vegyesebb kép rajzolódik ki. Míg előbbieknél Németországot inkább a férfiak, az Egyesült Királyságot pedig jellemzően a nők választották desztinációként, az orvosokat tekintve ennek pontosan az ellenkezőjét láthattuk. Ugyancsak kiemelendő szempont a németországi desztináció rendkívüli népszerüsége a fiatal orvosok körében. Különösen annak tükrében érdekes ez, hogy a teljes népesség kivándorlói közül Németországot általában az idősebbek választják nagyobb valószínűséggel. Ezzel szemben a teljes népesség emigránsai között a 30 év alattiak aránya leginkább az Egyesült Királyságban magas, amit jelen vizsgálatban sokkal inkább az ennél 
idősebb, tapasztaltabb orvosok körében azonositottunk kedvelt célországként. A hatósági bizonyítvány igénylések lakhely szerinti vizsgálatakor arra a következtetésre jutottunk, hogy - a teljes népességben látott trendeknek megfelelően - az orvosok közül szintén sokan választhatták az Ausztriába történő ingázás lehetőségét a nyugati határhoz közeli megyékben. Az pedig, hogy az Egyesült Királyság inkább a közép-magyarországi régió lakosai körében népszerü célpont, a teljes népességen túl a potenciális migráns orvosokra is jellemzőnek bizonyult.

Mindezek tükrében a legnépszerủbb célországokról a következö összegzéseket adhatjuk. Németországba leginkább a fiatal orvosok terveztek kivándorolni, a sokasági arányoknak megfelelően az ország valamennyi megyéjéből, illetve valamennyi orvosszakmai területről. Közöttük a nők voltak többségben. Ezzel szemben az Egyesült Királyság iránt inkább a 30 év feletti korcsoportokba tartozó, budapesti, Pest, illetve Csongrád megyei, férfi orvosok mutattak relatíve nagyobb érdeklődést. Kiemelendő, hogy akik ebbe az országba terveztek kivándorlást, azok magas százalékban ténylegesen meg is valósithatták e szándékukat. Köztük jelentős számban voltak az aneszteziológiai terület képviselői. Az Ausztriát megjelölők a nemi és korcsortok szerinti megoszlás tekintetében leképezték a sokasági arányokat, azonban a célország népszerűsége leginkább a határhoz közeli megyékben mutatkozott meg, ahonnan az ingázás könnyebben megoldható. Nyugati szomszédunknál főként az aneszteziológusok, a sebészek és a szülész-nőgyógyászok terveztek munkát vállalni. Svédország a főbb dimenziók mentén többnyire kiegyenlített képet mutatott, ám a 30 év alatti orvosok körében nem volt kedvelt célpont. Emellett a patológusok és a pszichiáterek, illetve a Baranya megyeiek terveztek relatíve nagyobb számban migrációt a skandináv országba. Svájcra leginkább a 40 év alattiak, a nők, illetve a budapestiek tekintettek potenciális desztinációként. Írország - amelyet jellemzően szintén a komolyabb kivándorlási szándékkal rendelkezők jelölték meg - főként a fiatalabbak, a férfiak, illetve a patológusok körében bizonyult relatíve népszerünek.

Eredményeink alapján tehát a fő célországokba történő migráció a hazai orvoshiány szempontjából különböző közpolitikai kihívásokat rejt magában. Az Ausztriába történő ingázás kisebb valószínűséggel szakítja el teljesen a hazai egészségügytől az orvosokat. Ez a veszély leginkább az Egyesült Királyságban munkát vállalók esetén áll fenn. A Németországba történő vándorlás pedig azért jelenthet problémát, mert a fiatal, pályakezdő orvosok elszivása révén még jobban hozzájárul az orvosszakma elöregedéséhez Magyarországon.

Mindezek feltárásával tanulmányunk új, a szakirodalomban eddig nem ismert részletekkel járult hozzá a magyarországi orvos-elvándorlás jelenségének teljesebb megismeréséhez. Eredményeink emellett a közpolitika alakítói számára is 
relevanciával bírnak hazai és európai szinten egyaránt. A célország-preferenciák esetén tapasztalt, statisztikai értelemben gyenge kapcsolatok ugyanis arra utalnak, hogy a magyar orvosok külföldi munkavállalását elsősorban a taszító (push) hatások mozgatják, s az ezen felül megjelenő kereslet oldali vonzó (pull) hatások ugyan jól beazonosithatók, de másodlagosak lehetnek. Utóbbiak jelenléte, és azok migrációt befolyásoló szerepe egy heterogén, ám a szabad mozgás lehetőségét biztosító nemzetközi térben természetes. Ezzel együtt a push faktorok kezelése, s a taszítás csökkentése a származási ország kormányzatára ró további felelősséget. Mindazonáltal az Uniós intézményi keret adta sajátosságok miatt az agyelszívás (brain drain) negatív hatásainak (bővebben lásd például Golovics, 2019) csökkentése érdekében az európai szintű gondolkodás megindítása is indokolt lehet. Ezt támasztják alá az elöregedő orvostársadalommal és alacsony kibocsátású orvosképzéssel bíró országok oldaláról jelentkező vonzó-hatásokra vonatkozó eredményeink. A növekvő egészségügyi keresletre és az ezzel párhuzamosan az orvosképzésben megfigyelhető egyenlőtlenségek (kibocsátás, ráfordítás) okozta kihívásokkal ugyanis egy egységesülni kívánó Európa leginkább egy egységes, központi szintủ válasszal tudna hatékonyan szembenézni 


\section{IRODALOM}

Állami Egészségügyi Ellátó Központ (2020). Migrációs statisztikák. ÁEEK által a szerző részére rendelkezésre bocsájtott adatok.

Balázs P. (2012). Orvosi létszámok és a nemzetközi orvosmigráció aktuális hatása Magyarországon. Orvosi Hetilap, 153(7), 250-256.

Blaskó Zs., Ligeti A. S. és Sik E. (2014). Magyarok külföldön - Mennyien? Kik? Hol? In Kolosi T. - Tóth I. Gy., (szerk.), Társadalmi Riport 2014 (351-372. o.). Budapest: TÁRKI.

Boros L. és Pál V. (2016). A magyarországi orvosmigráció néhány jellemzője. Északmagyarországi Stratégiai Füzetek 13(1), 64-72.

Eurostat (2021). Population on 1 January by age group, sex and citizenship [migr_ pop1ctz]. Elérhető: https://ec.europa.eu/eurostat/databrowser/bookmark/1339e08efaf1-493d-b30a-b0920b7af11c?lang=en

Eurostat (2022a). Job vacancy statistics by NACE Rev. 2 activity - quarterly data (from 2001 onwards) [JVS_Q_NACE2]. Elérhető: https://ec.europa.eu/eurostat/ databrowser/bookmark/59cc1c01-4fc6-40c2-8514-7240cda26074?lang=en

Eurostat (2022b). Physicians by medical speciality [HLTH_RS_SPEC]. Elérhető: https://ec.europa.eu/eurostat/databrowser/bookmark/36e67bcc-3c5d-43ea-94123aa4467ec11e?lang=en

Girasek E., Csernus R., Ragány K. és Eke E. (2013). Migráció az egészségügyben. Magyar Tudomány, 174(3), 292-298.

Glinos, I. A. (2014). Going beyond numbers: A typology of health professional mobility inside and outside the European Union. Policy and Society, 33(1), 25-37.

Golovics, J. (2019). Addressing the EU's East-West Brain Drain: Why a Tax Solution Would Be in Vain. New Perspectives, 27(2), 63-85.

Golovics J. és Zsinkó M. (2020). A magyar orvostanhallgatók elvándorlási szándékainak befolyásoló tényezői. In Cserháti l., (szerk.), Munkapiaci trendek-demográfiai és jóléti kihívások (236-251. o.). Budapest: Typotex Kiadó.

Golovics J. és Zsinkó M. (2021). A magyar orvosmigráció jellemzői a 2010-es években. Magyar Tudomány, 182(2), 240-248.

Gödri I. (2018). Nemzetközi vándorlás. In Monostori, J., Öri, P. és Spéder, Zs., (szerk.), Demográfiai Portré 2018 (237-270. o.). Budapest: KSH Népességtudományi Kutatóintézet.

Győrffy, Zs., Dweik, D. and Girasek, E. (2018). Willingness to migrate - a potential effectof burnout? A survey of Hungarian physicians. Human Resources for Health, 16(36), 1-8.

Hárs Á. és Simon D. (2016). Miért mennek el az orvosok - és miért maradnának itthon? I. rész. A magyarországi orvosmigráció sajátosságairól. Külgazdaság, 60(5-6), 3-26.

Jonsson, R., Lindegård, A., Björk, L. and Nilsson, K. (2020). Organizational Hindrances to the Retention of Older Healthcare Workers. Nordic Journal of Working Life Studies, 10(1), 41-58.

Kovács E. és Sipos N. (2020). Mobilitás a határmenti régiókban - Ausztria. Pécsi Munkajogi Közlemények, 13(Különszám), 14-31.

Központi Statisztikai Hivatal (2022). Üres álláshelyek száma és aránya nemzetgazdasági áganként, negyedévente. Elérhető: https://www.ksh.hu/stadat_files/mun/hu/ mun0159.html

Lorkowski, J. and Jugowicz, A. (2020). Shortage of Physicians: A Critical Review. In Pokorski M. (eds) Medical Research and Innovation. Advances in Experimental Medicine and Biology (57-61. o.). Springer, Cham. https://doi.org/10.1007/5584_2020_601 
Massey, D. S., Arango, J., Hugo, G., Kouaouci, A., Pellegrino, A. and Taylor, E. J. (1993). Theories of International Migration: A Review and Appraisal. Population and Development Review, 19(3), 431-466.

Organisation for Economic Co-operation and Development (2021). Health at a Glance 2021: OECD Indicators. Paris: OECD Publishing. Elérhető https://doi.org/10.1787/ ae3016b9-en.

Országos Kórházi Főigazgatóság (2022). Tájékoztató a tartósan betöltetlen háziorvosi körzetekről. Elérhető: https://alapellatas.okfo.gov.hu/tajekoztato-a-tartosanbetoltetlen-haziorvosi-korzetekrol/

Sik E. (2003). A migrációs potenciál kutatásának alapfogalmai. In Örkény A., (szerk.), Menni vagy maradni? Kedvezménytörvény és migrációs várakozások (15-18. o.). Budapest: MTA Kisebbségkutató Intézet.

Varga J. (2016). Hova lettek az orvosok? Az orvosok külföldre vándorlása és pályaelhagyása Magyarországon, 2003-2011. Közgazdasági Szemle, 63(1), 1-26.

Varga J. (2020). Az orvosok elvándorlása 2009-2017 között. In Fazekas K., Elek P. és Hajdu T., (szerk.), Munkaerőpiaci Tükör 2019 (147-150. o.). Budapest: Közgazdaság- és Regionális Tudományi Kutatóközpont. 


\title{
DESTINATION COUNTRY PREFERENCES AMONG HUNGARIAN POTENTIAL MIGRANT PHYSICIANS
}

\begin{abstract}
This paper focuses on destination country preferences of Hungarian potential migrant physicians between 2010 and 2019, based on data about official certificate required for employment in a foreign country, issued by National Healtcare Service Center. Besides presenting statistics, we perform crosstable analyzes to examine the patterns of destination country preferences by physician's sex, age, place of residence and type of specialist exam. Pull effects from the side of destination countries are analyzed as well. Although results show weak association, several specific motifs may be highlighted. There is a very strong interest among young physicians towards Germany, while the UK is popular among more experienced physicians. Besides, those who intend to migrate to the UK are more likely to implement these plans. Austria is a potential commuting destination for physicians in counties close to the western border, while Sweden is highly preferred by pathologists.
\end{abstract}

Keywords: migration, emigration, healthcare migration 


\section{MELLÉKLET}

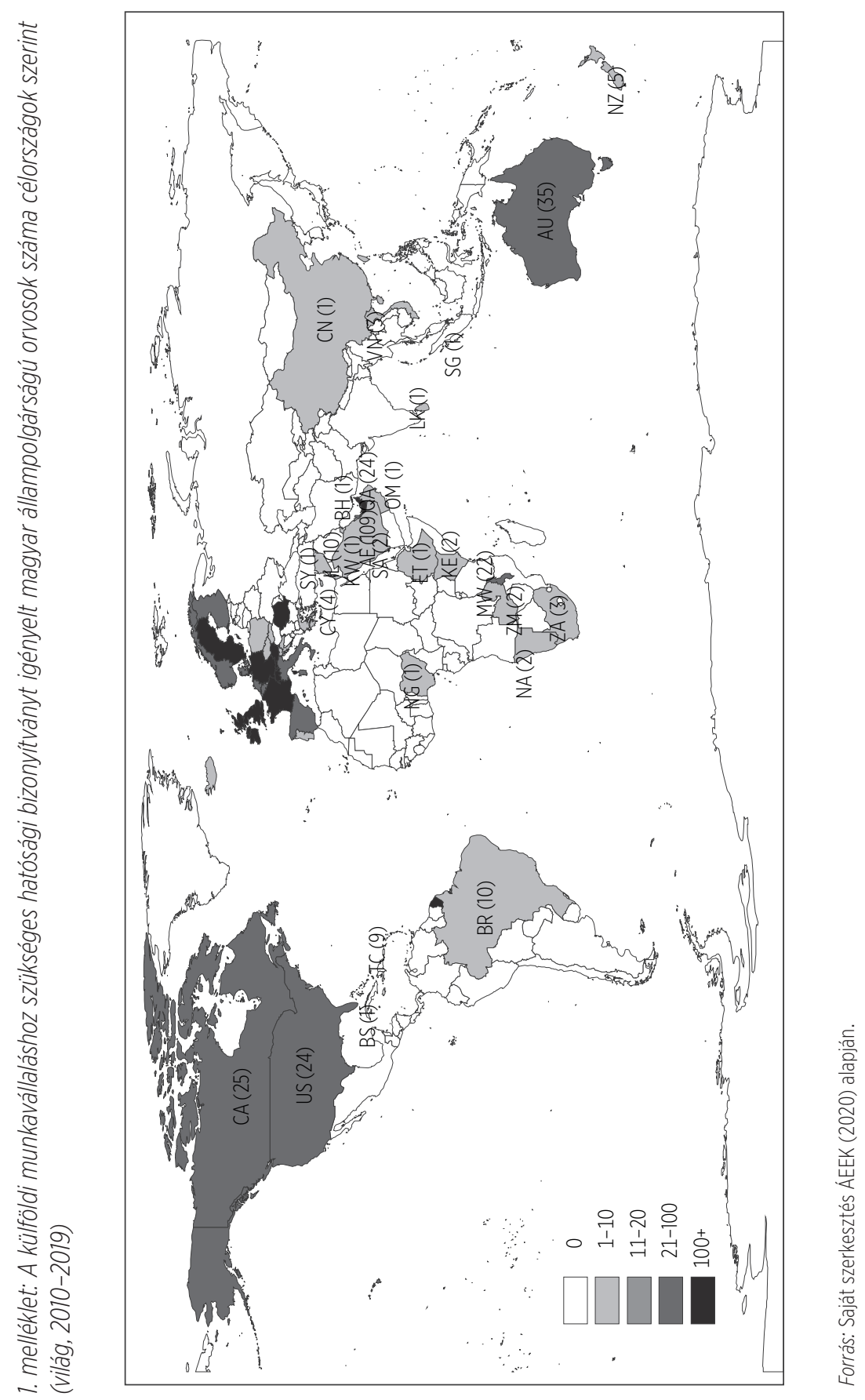


2. melléklet: A vényfelíróként meg nem jelenő potenciális migráns orvosok száma a fö célországok és nemek szerinti bontásban, 2010-2019 (fö és megoszlási arányok zárójelben)

$\begin{array}{lccr} & \text { Férfi } & \text { Nő } & \text { Összesen } \\ \text { Németország } & 596(44 \%) & 768(56 \%) & 1364(100 \%) \\ & (39 \%) & (44 \%) & (42 \%) \\ \text { Egyesült Királyság } & 387(51 \%) & 370(49 \%) & 757(100 \%) \\ \text { Ausztria } & (26 \%) & (21 \%) & (23 \%) \\ & 182(46 \%) & 217(54 \%) & 399(100 \%) \\ \text { Svédország } & (12 \%) & (12 \%) & (12 \%) \\ & 178(49 \%) & 187(51 \%) & 365(100 \%) \\ \text { Svájc } & (12 \%) & (11 \%) & 223(100 \%) \\ & 94(42 \%) & 129(58 \%) & (7 \%) \\ \text { Írország } & (6 \%) & (7 \%) & 144(100 \%) \\ \text { Összesen } & 75(52 \%) & 69(48 \%) & (4 \%) \\ & (5 \%) & (4 \%) & 3252(100 \%) \\ & 1512(46 \%) & (100 \%) & (100 \%)\end{array}$

Megjegyzés: Az orvosok létszám-adatai alatt zárójelben szereplő százalékos értékek a nemen belüli célországonkénti megoszlást, míg az értékektől jobbra elhelyezkedő, zárójelben szereplő százalékos értékek a célországon belüli, nemi megoszlást mutatják.

Forrás: Saját szerkesztés ÁEEK (2020) alapján. 


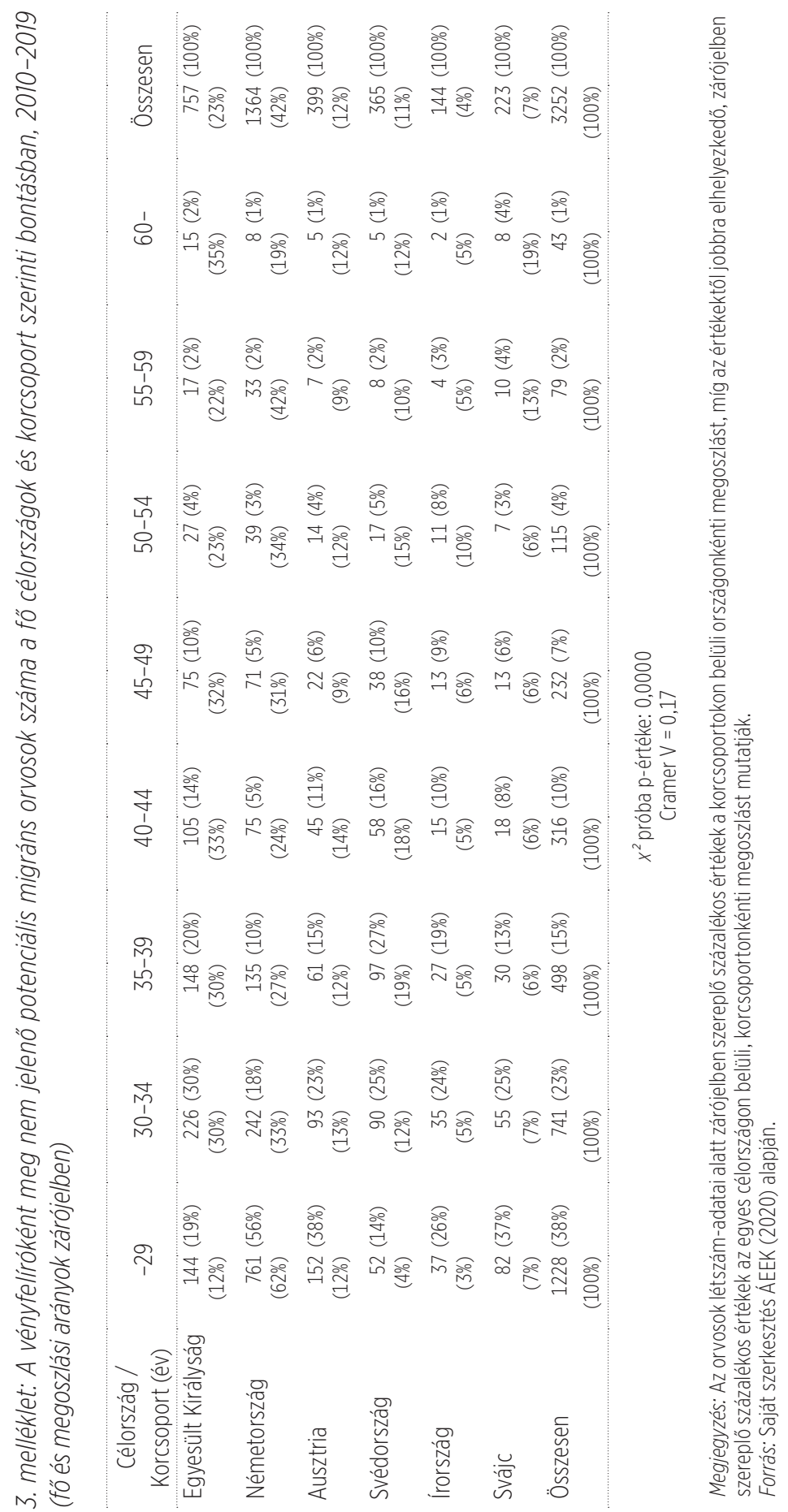


政

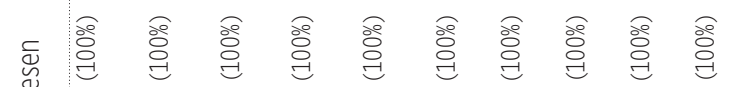

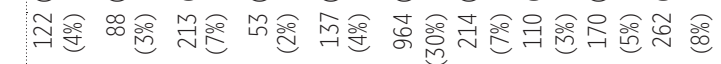

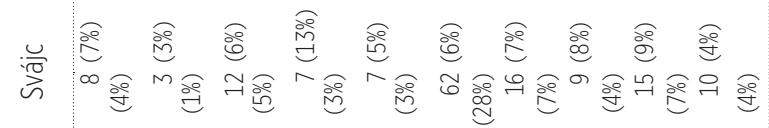

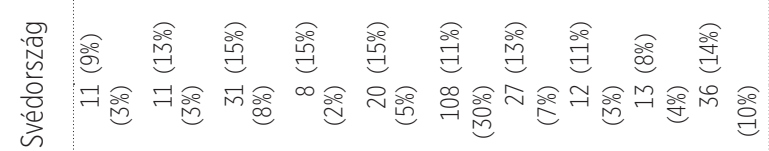

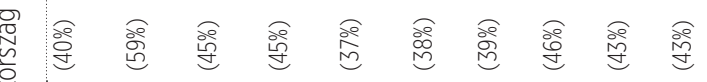

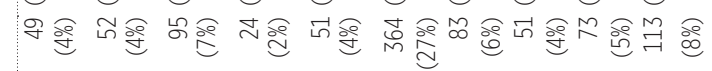

$$
\begin{aligned}
& \text { 产 }
\end{aligned}
$$

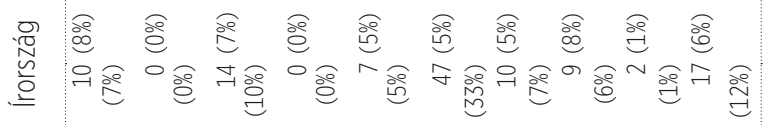

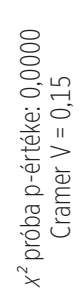

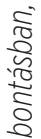$$
\text { 旁 }
$$$$
\text { (4) }
$$$$
\text { है }
$$$$
\text { वे }
$$

齐

产

$\frac{\sqrt{2}}{\sqrt[0]{0}}$

$\frac{\sqrt{2}}{\frac{5}{0}}$

$\frac{1}{\frac{1}{2}}$

है 


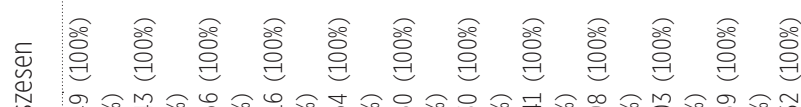

웡

$\frac{\sqrt{0}}{\frac{\pi}{0}}$

:

¿

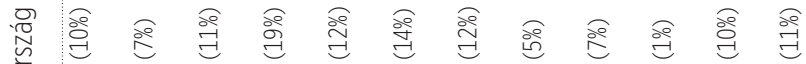

:

(2)

$\frac{\overline{0}}{\overline{0}}$

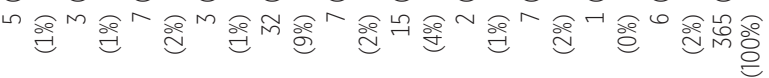

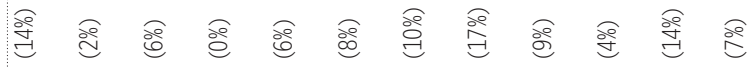

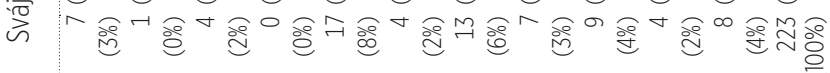

$\ddot{c}$

के

这

过

$\frac{8}{6}$

$\sum_{\substack{\infty \\ \infty}}^{\infty}$

ठั้

ᄒ

$\stackrel{\frac{\pi}{2}}{\frac{2}{2}}$

$\frac{8}{\frac{2}{2}}$

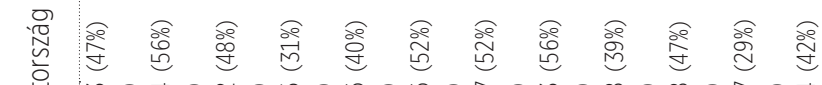

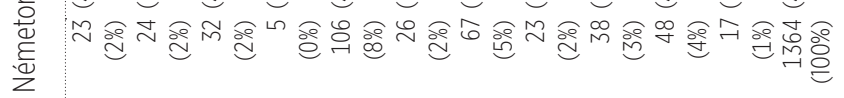

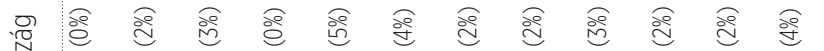

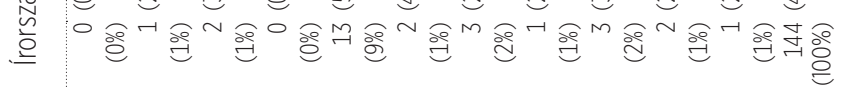

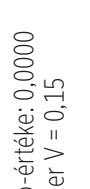

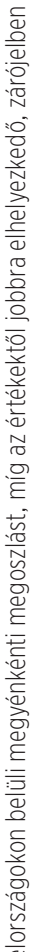

$\frac{0}{0} \frac{0}{0}$

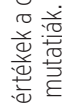

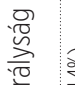

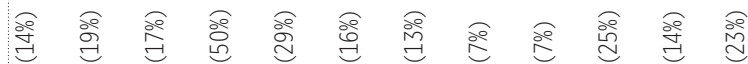

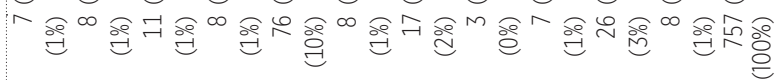

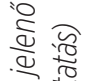

엄

$\frac{\varepsilon}{\infty} \frac{2}{2}$

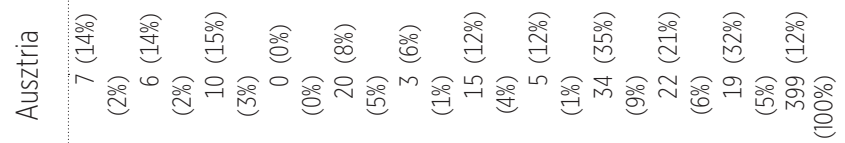

है छ

$\frac{2}{2}$

$\frac{\sqrt{2}}{\sqrt[2]{2}}$

के

迹 $\frac{\sqrt{0}}{\frac{9}{2}}$

व.

×

造 考

:

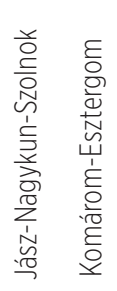

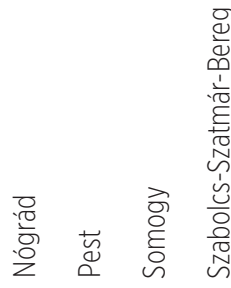

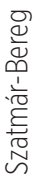

है

$\forall$ 迟

峁

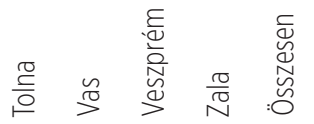

岁蔡

胥

종

응 등

늠

동

응

兽溶这

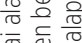

픔

केढิ

है

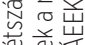

这

员老

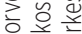

중



긍

बे

는 


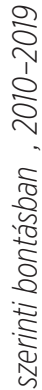

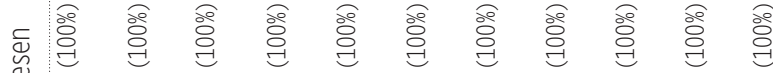

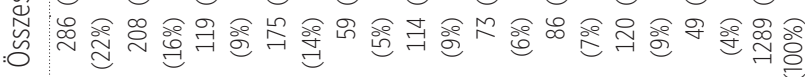

产

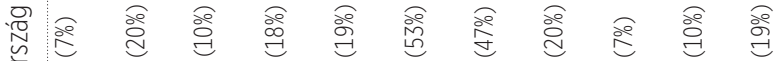

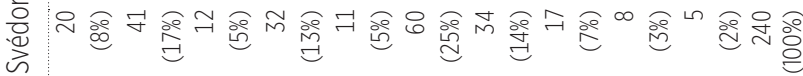

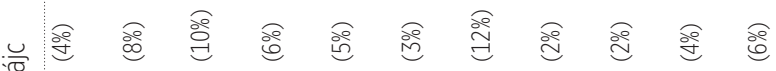
覀 7 存

รั)

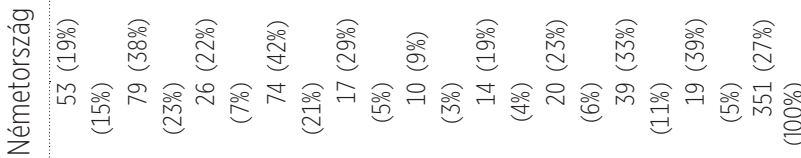

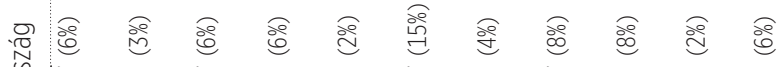
.

$\frac{.2}{\frac{\pi}{5}}$

.

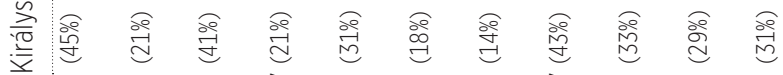

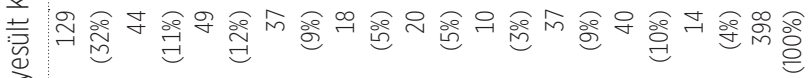
亭

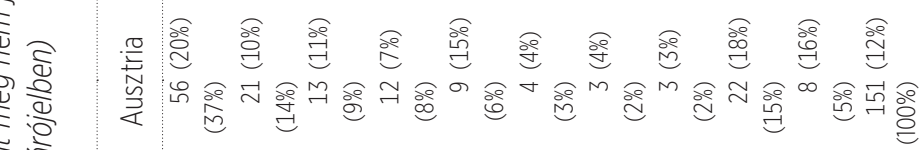
제에 : ํํㅇ

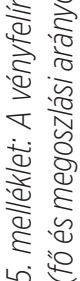
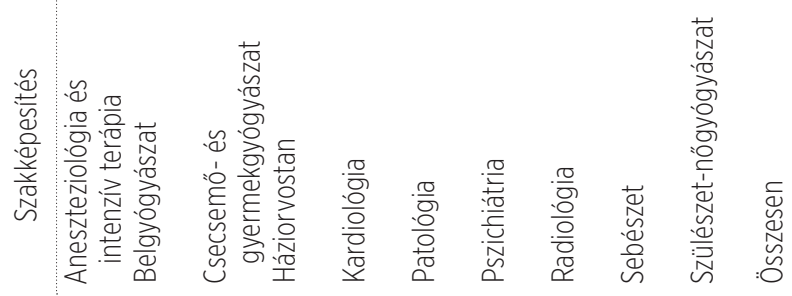